\title{
Pancreatic cytokeratin: an antigen of pancreatic exocrine cell autoantibodies in Type 1 (insulin-dependent) diabetes mellitus
}

\author{
T.Kobayashi ${ }^{1}$, K. Nakanishi ${ }^{1}$, H. Kajio ${ }^{3}$, S. Morinaga ${ }^{2}$, T. Sugimoto ${ }^{1}$, T. Murase ${ }^{1}$ and K. Kosaka ${ }^{1}$ \\ ${ }^{1}$ Department of Endocrinology and Metabolism, \\ 2 Department of Haematology, Toranomon Hospital, and Okinaka Memorial Institute for Medical Research, and \\ ${ }^{3}$ The Institute for Diabetes Care and Research, Asahi Life Foundation, Tokyo, Japan
}

\begin{abstract}
Summary. Autoantibodies reacting with human pancreatic exocrine cells were investigated by immunofluorescent techniques in 107 patients with Type 1 (insulin-dependent) diabetes mellitus, 20 first-degree relatives of the Type 1 diabetic patients, 347 patients with Type 2 (non-insulin-dependent) diabetes, 34 with alcoholic pancreatitis, 26 with rheumatoid arthritis and 107 normal control subjects. Both immunoblotting analysis and double-immunostaining methods were used to characterize the antigens targeted by the pancreatic exocrine cell autoantibodies. Sera positive for human pancreatic exocrine cell cytoplasm, producing a "fine fibrillar" pattern, were found in $21 \%$ (23/107) of the Type 1 diabetic patients. The autoantibodies were present in $39 \%$ (15/38) of Type 1 diabetic patients diagnosed within 3 months, and the prevalence decreased with duration of diabetes. The antibodies were of the IgM class in $87 \%(13 / 15)$ of recent-onset Type 1 diabetes cases, but IgG-autoantibodies became more prevalent with increasing duration of
\end{abstract}

diabetes. Three out of $347(0.9 \%)$ Type 2 diabetic patients and 4 of $20(20 \%)$ first-degree relatives of Type 1 diabetic patients had autoantibodies targeted against pancreatic exocrine cells. None of the patients with alcoholic pancreatitis or rheumatoid arthritis and none of the control subjects had these antibodies. Immunoblotting analysis and double-immunostaining demonstrated that the autoantibodies reacted with 40 kilodalton cytokeratin in pancreatic exocrine cell cytoplasm. The antibody was absorbed by the Triton X-100-insoluble fraction of pancreatic extract. These results indicate the presence of distinct autoantibodies to pancreatic exocrine cells in Type 1 diabetes. This suggests the provocative concept that the cytoskeletal system of pancreatic exocrine cells is involved in the pathogenetic process of Type 1 diabetes.

Key words: Pancreatic exocrine cell antibodies, cytokeratin, Type 1 (insulin-dependent) diabetes mellitus, islet cell antibodies, pancreatic exocrine cells, pancreatic islet.
Recent studies have demonstrated that the exocrine pancreas as well as the pancreatic islets can be involved in Type 1 (insulin-dependent) diabetes mellitus [1-3]. The pathological changes detected have included lymphocytic infiltration of pancreatic exocrine tissue $[1,2]$ and the transient elevation of pancreas-specific enzymes [3]. These reports have suggested other abnormalities of the pancreatic exocrine system in Type 1 diabetes $[4,5]$. In this context, it is of interest to investigate the presence of autoantibodies against pancreatic exocrine tissue. Autoantibodies to pancreatic acinar cells have been a subject of controversy in acute and chronic pancreatitis [6-9]. Furthermore, there is a dearth of knowledge on the presence of autoantibodies to exocrine cells in patients with Type 1 diabetes. Autoantibodies reacting to the interstitial tissue of pancreatic acinar cells have been reported in two cases of neonatal Type 1 diabetes [10].

In a preliminary study, we found that some sera of Type 1 diabetic patients yielded filamentous cytoplasmic staining patterns, suggesting the presence of autoanti- bodies to the cytoskeletal structure of pancreatic acinar cells. In the present study, therefore, we focussed on clarifying the presence of pancreatic exocrine cell autoantibodies, especially those directed against cytoplasmic structures in Type 1 diabetes. Characterization of the cytoplasmic antigen in human pancreatic exocrine cells was also performed.

\section{Subjects and methods}

\section{Subjects}

Sera were sampled from the following subjects: (a) 38 recent-onset (less than 3 months) patients with Type 1 diabetes [male/female $(\mathrm{M} / \mathrm{F}): 15 / 23$, mean age: 16 years $(2-45)$, mean duration: 1 month, (0-2.9 months)]; (b) 69 patients with Type 1 diabetes of more than 3 months duration [M/F: 35/34, mean age: 44 years (13-74), mean duration: 11 years ( 3 months -47 years)]; (c) 20 first-degree relatives of Type 1 diabetic patients [13 parents (father/mother): 8/5, mean age: 57 years (48-71), 3 siblings (M/F): 2/1, mean age: 33 years 
(21-52), 4 offspring (M/F): 2/2, mean age 17 years $(7-29)]$; (d) 347 patients with Type 2 (non-insulin-dependent) diabetes mellitus [M/F: 225/122, mean age: 52 years (17-82), mean duration: 7 years (0-29)]; (e) 34 patients with alcoholic pancreatitis [M/F: 29/5, mean age: 52 years (34-68)]; (f) 26 patients with rheumatoid arthritis (RA) [M/F: 6/20, mean age: 61 years (44-74)], and (g) 107 healthy normal control subjects matched for age and sex with the Type 1 diabetic patients [M/F: 50/57, mean age: 35 years (2-80)]. Three recent-onset Type 1 diabetic patients were followed up to 14 months. All samples collected were frozen at $-80^{\circ} \mathrm{C}$ until assay.

Diabetes mellitus was categorized according to the guidelines of the National Diabetes Data Group [11]. There was no evidence of mixed connective tissue disease in the Type 1 diabetic patients, the first-degree relatives of the Type 1 diabetic patients, the Type 2 . diabetic patients, the patients with alcoholic pancreatitis or the healthy normal control subjects. None of the subjects were complicated with other organ-specific autoimmune diseases. The protocol was approved by the Comittee on Investigation Involving Human Subjects at the Toranomon Hospital. Informed consent was obtained from each subject.

\section{Immunofluorescence method for detecting human pancreatic exocrine cell autoantibodies}

Pancreatic exocrine cell autoantibodies were tested for by the indirect immunofluorescence method using $3-\mu \mathrm{m}$ unfixed cryostat sections of blood group 0 human pancreata surgically removed from non-diabetic gastric carcinoma patients. Acetone-fixed section (for $1 \mathrm{~min}$ ) was also used to evaluate the effect of fixation on the staining pattern. The samples were diluted $1: 4$ with $10 \mathrm{mmol} / \mathrm{l}$ phosphatebuffered saline (PBS) ( $\mathrm{pH} 7.2)$ and then applied to the sections. They were then incubated at room temperature for $30 \mathrm{~min}$ in a moist chamber. The sections were subsequently incubated for $30 \mathrm{~min}$ at room temperature with fluorescein-isothiocyanate (FITC)-conjugated goat antisera to human whole immunoglobulin, IgG, IgA, and IgM (Dakopatts, Glostrup, Denmark) diluted to 1:15 with PBS. Each incubation was followed by washing three times for $5 \mathrm{~min}$ with PBS. Slides were then mounted in $90 \%$ glycerol buffered with $0.5 \mathrm{~mol} / \mathrm{l}$ carbonate buffer ( $\mathrm{pH} 9.5$ ) and were examined using a Nikon Optiphot with epiillumination.

Sera were also tested against unfixed and acetone fixed (for $1 \mathrm{~min}$ ) cryostat sections of fresh human salivary gland, pituitary gland, stomach, liver, kidney, oesophagus, and skin.

\section{Identification of cytoplasmic antigen of pancreatic exocrine cell autoantibodies by double-immunostaining and immunoblotting analysis}

Double-immunofluorescence staining of cryostat human pancreatic sections was carried out using patients' serum followed by incubation with FITC-conjugated anti-human IgM, IgG or IgA serum (Dakopatts) and mouse monoclonal IgG against cytoskeletal components. Mouse IgG was visualized by incubation with biotinated antimouse IgG followed by incubation with rhodamine-avidin complex (Vector Co. Burlingame, Calif., USA). The antibodies against cytoskeletal components used included monoclonal mouse anticytokeratin antibodies (CAM 5.2: Becton-Dickinson, Mountain View, Calif., USA and PKK1: Labsystem, Helsinki, Finland), mouse antivimentin antibody (V9: Dakopatts) mouse antidesmine antibody (DE-R-11: Dakopatts), antineuroglial filament antibody (NR4, Dakopatts), and mouse antitubulin antibody (YOL 1/34: Serotec Labs., Sapporo, Japan). Antiserum to pepsinogen (a gift from Dr. M. Chiba, Kobe University, Kobe, Japan) was also used.

The effect of Triton X-100 on the antigen preservation of pancreatic exocrine cell antibodies and islet cell antibodies (ICA) was examined as follows. The pancreatic sections were incubated with $0.5 \%$ Triton X-100 (Sigma, St Louis, Mo., USA) in PBS, pH 7.4 for
1 min at $25^{\circ} \mathrm{C}$. After washing with PBS, the patients' serum samples were applied on the sections and stained by the methods for pancreatic exocrine cell antibodies and ICA. To test for double-immunostaining specificity, the following experiments were conducted. Omission was carried out on the staining steps including the application of patients' serum, incubation with FITC-conjugated antihuman immunoglobulins (IgM, IgG or IgA), application of mouse monoclonal IgG against cytoskeletal components, or rhodamineavidin complex. Consecutive pancreatic sections $(3 \mu \mathrm{m})$ were also stained using patients' serum followed by FITC conjugated antihuman immunoglobulins or antibodies against cytoskeletal components. The absorption of the autoantibodies was investigated using the tissue fraction of cytoskeletal components as follows. Fresh human pancreatic tissue $(2 \mathrm{~g})$ was minced and rinsed 3 times with chloroform and methanol (6:1, volume/volume). The tissue was homogenized in $10 \mathrm{ml}$ of $1 \%$ Triton X-100-0.6 mol/ $\mathrm{KC} 1-0.1 \mathrm{mmol} / \mathrm{l}$ phenylmethylsulfonyl fluoride (PMSF) at $4^{\circ} \mathrm{C}$ using a Polytron (Kinematica Co., Luzern, Switzerland). Pellets obtained after centrifugation at $5000 \mathrm{~g}$ for $10 \mathrm{~min}$ were washed with $0.1 \mathrm{mmol} / \mathrm{l} \mathrm{PMSF}$ PBS and then used as the cytoskeletal component [12]. The pellets were resuspended in PBS using $0.5 \mathrm{ml}$ per gramme of original tissue. Human salivary gland, skin and liver were also subjected to the processing described above. Sera were diluted 1:2 in PBS and absorbed overnight at $4^{\circ} \mathrm{C}$ with an equal volume of the cytoskeletal component of each organ.

The cytoskeletal component of the pancreas and salivary gland obtained as described above was kept at $95^{\circ} \mathrm{C}$ for 2 min in $1 \%$ sodium dodecyl sulfate (SDS)- $0.192 \mathrm{~mol} / \mathrm{l}$ glycine- $25 \mathrm{mmol} / \mathrm{l}$ tris- $5 \%$ beta-mercaptoethanol-1 mmol/1 EDTA (pH 8.3), and then centrifuged at $10000 \mathrm{~g}$ for $30 \mathrm{~min}$. The supernatants were separated by SDS-polyacrylamide-gel electrophoresis (SDS-PAGE) [13], and were then transferred to nitrocellulose paper. Immunostaining by an indirect peroxidase method was performed using the patients' sera at a dilution of 1:100 and the monoclonal antibodies against cytoskeletal components described above.

\section{Detection of ICA and elastase 1}

ICA was assayed by indirect immunofluorescence method as previously described $[14,15]$. The quality of our ICA assay was evaluated by the 3rd International Workshop on the Standardization of ICA as follows; cutoff: 5 JDF units, sensitivity: $90 \%$ specificity: $92 \%$. Serum elastase- 1 level was measured by specific RIA with a normal range of $103-334 \mathrm{ng} / \mathrm{dl}[16]$.

\section{Statistical analysis}

Spearman's correlation test was applied to compare ICA titres and those of pancreatic exocrine cell antibodies. Fisher's exact test was employed in the statistical calculations to compare the prevalence.

\section{Results}

Detection of autoantibodies against human pancreatic exocrine cells and identification of cytoplasmic antigens by double-immunostaining and immunoblotting analysis

The indirect immunofluorescence method demonstrated the presence of immunoglobulins that reacted with the characteristic "fine fibrillar" intra-cytoplasmic structure of the pancreatic acinar cells and duct cells in some patients with Type 1 diabetes, first-degree relatives of Type 1 diabetic patients, and a few with Type 2 diabetes (Fig. 1a). The staining pattern of acetone-fixed sec- 


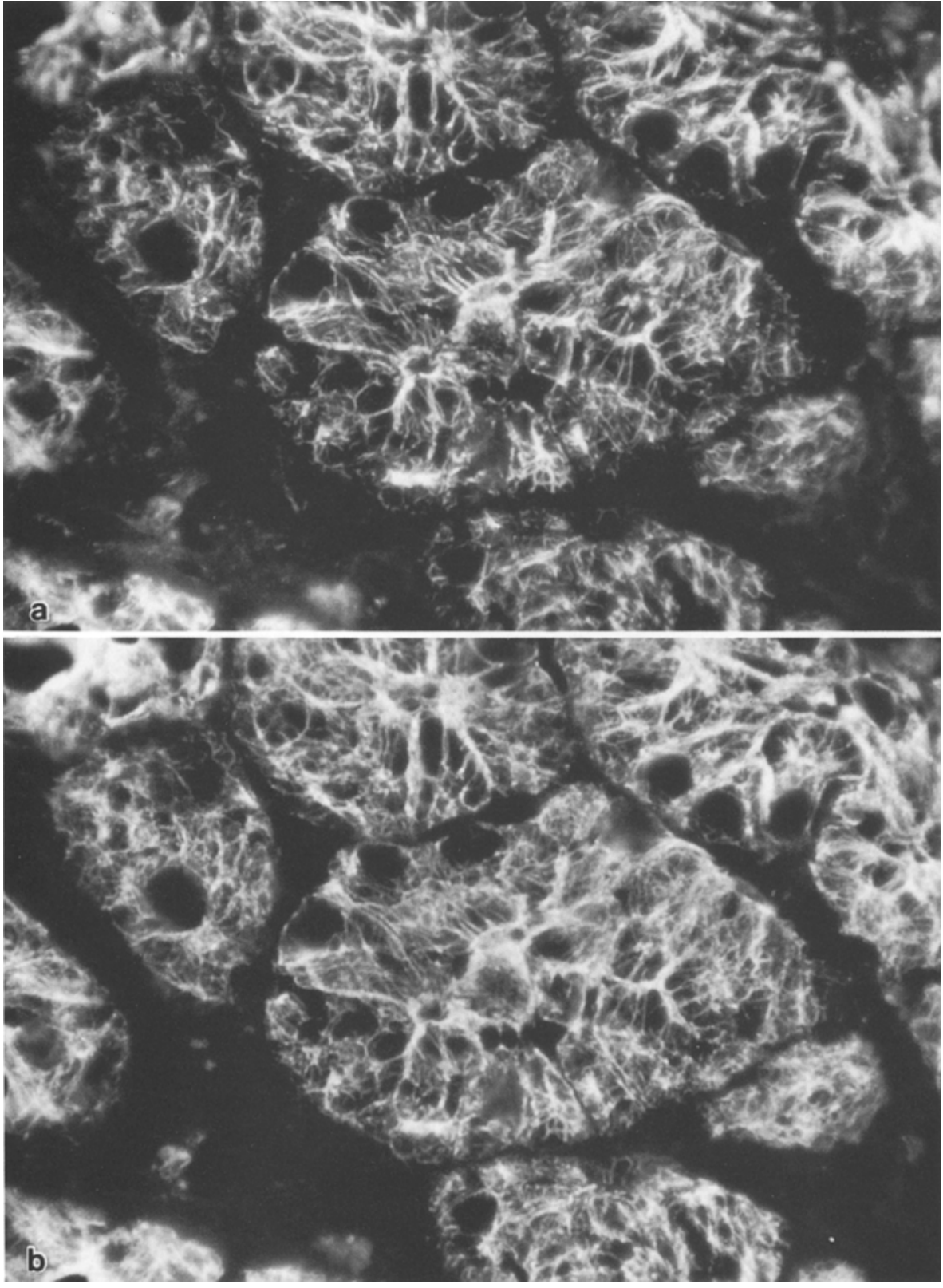

Fig. 1a, b. Double-immunostaining of human pancreatic acinar cells by serum from a patient with Type 1 (insulindependent) diabetes mellitus (a), and by monoclonal antibody to cytokeratin (CAM 5.2) (b). The fine fibrillar cytoplasmic fluorescence stained by the patient's serum (a) seemed concordant with the keratin filaments stained by cytokeratin antibodies (CAM 5.2) (b). Original magnification: $\times 308$ tion did not differ from that of unfixed one. The characteristic "fine fibrillar" cytoplasmic fluorescence was detected in 23 of 107 (21\%) patients with Type 1 diabetes, 4 of $20(20 \%)$ first-degree relatives of Type 1 diabetic patients (1 father, 1 sibling, and 2 offspring), and in 3 of $347(0.9 \%)$ patients with Type 2 diabetes. The Ig subclass of the autoantibodies among fluorescentpositive patients with Type 1 diabetes was $\operatorname{IgM}$ in $65 \%$ (15/23), IgG in $26 \%(6 / 23)$, and both IgM and $\operatorname{IgG}$ in $9 \%$ (2/23). Antibodies staining pancreatic exocrine cell cytoplasm with a "fine fibrillar" pattern were not detected in the 34 patients with alcoholic pancreatitis, the 26 patients with rheumatoid arthritis or the 107 control subjects.

The "fine fibrillar" pattern of the cytoplasmic antigens suggested that the antibodies recognized specific antigenic determinants of the cytoskeletal components. Double immunostaining suggested that acinar cell cy- tokeratin filaments, which were stained by rhodamine-labelled anticytokeratin monoclonal antibodies (CAM 5.2 and PKK1), were concordant with the cytoplasmic antigens stained by FITC-labelled antihuman immunoglobulins (Figs. $1 \mathrm{a}$ and $\mathrm{b}$ ). The antibodies were also positive for pancreatic duct cells, and the staining pattern of the interlobular duct cells was also concordant with the staining pattern for anti-cytokeratin antibodies (CAM 5.2 and PKK1). The positive samples for pancreatic exocrine cell cytoplasm (titre: more than 1:32, $n=14$ ) also reacted weakly to the cytoplasm of islet cells (Fig. 2). They were all of $\operatorname{IgM}$, and were positive for islets as well as pancreatic exocrine cells on Triton X-100-treated sections. In contrast, all samples positive for ICA were of IgG, and reactivity to islet cell cytoplasm was not detected on Triton X100 -treated sections. Double immunostaining showed that the positive fluorescence pattern of the islet stained by patients' sera was concordant with the staining pattern 


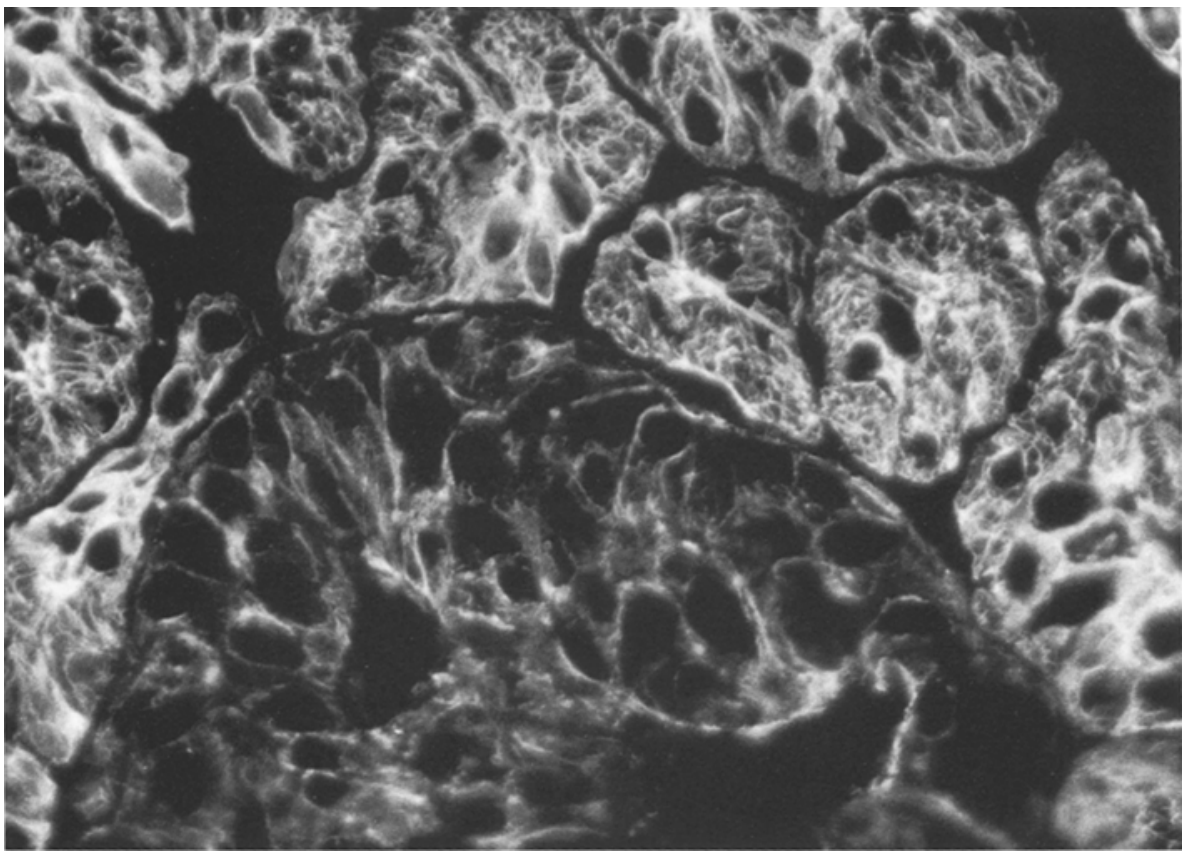

Fig. 2. IgM autoantibodies to the cytokeratin of pancreatic exocrine cells also showed weakly positive staining of the islet cell cytoplasm. Doubleimmunostaining study also showed that the autoantibodies were against islet cytokeratin. Original magnification: $\times 154$

stained by anti-cytokeratin monoclonal antibodies (CAM 5.2 and PKK 1).

Neither tubulin, vimentin, desmin nor neuroglial filaments were stained in the cytoplasm of pancreatic exocrine cells. Control experiments were consistently negative. The study with consecutive pancreatic sections showed that the "fine fibrillar" cytoplasmic fluorescence stained with 23 Type 1 diabetic patients' sera were similar with the staining pattern of pancreatic cytokeratin filaments.

The sera producing the "fine fibrillar" immunofluorescence pattern in the exocrine pancreatic cytoplasm and positive reaction to islet cells were completely absorbed by the Triton X-100-insoluble pancreatic fraction, but not

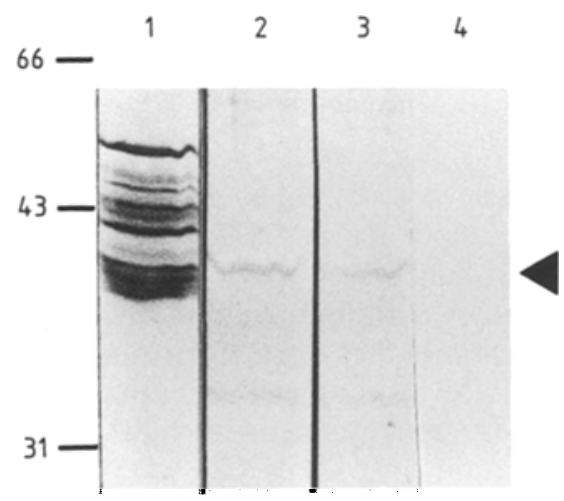

Fig.3. Identification of cytokeratin polypeptides reacted with sera from the patients with Type 1 (insulin-dependent) diabetes mellitus by immunoblotting. Lane 1 shows cytokeratin bands immunostained by specific monoclonal antibody against cytokeratin (CAM 5.2). Lanes 2 and 3 show immunostaining with sera from two Type 1 diabetic patients, who showed positive immunofluorescence of their pancreatic cytokeratin filaments by double immunostaining. A band corresponding to 40 kilodalton cytokeratin was stained (arrowhead). A light band of lower molecular weight also stained, but was not consistently detectable in other experiments. Lane 4: normal control subject's serum by the Triton X-100-insoluble fractions of the salivary gland, liver or skin.

Immunoblotting analysis showed that the autoantibodies, which showed positive immunofluorescence for pancreatic cytokeratin filaments by double immunostaining, reacted with the corresponding band of 40 kilodalton pancreatic cytokeratin (Fig. 3). The autoantibodies failed to react with cytoskeletal fraction from salivary gland.

These results indicated that one of the antigens for these autoantibodies was pancreatic cytokeratin.

\section{Tissue specificity of immunofluorescent reactions in} Type 1 diabetes, first-degree relatives of Type 1 diabetic patients, Type 2 diabetes, alcoholic pancreatitis, and $R A$

The sera of 3 of 23 patients with Type 1 diabetes which gave positive "fine fibrillar" immunofluorescence to the pancreas also gave positive reactions with pepsinogencontaining chief cells of the stomach (Figs. $4 \mathrm{a}$ and b). Double-immunostaining showed that the immunofluorescence reaction was also against cytokeratin in the gastric chief cells. The sera from 23 patients with Type 1 diabetes, 4 first-degree relatives of Type 1 diabetic patients, and 3 with Type 2 diabetes, which were positive for the pancreas, did not react with human salivary gland, pituitary gland, kidney, liver, oesophagus or skin, despite the presence of cytokeratin peptides in these tissues. Sixty-two percent (16/26) of the sera from RA patients showed positive staining of the keratinized layer of the skin. However, none reacted with the remaining tissues, including pancreas, salivary gland, pituitary gland, stomach, kidney, liver and oesophagus. None of the samples from the 34 patients with alcoholic pancreatitis or from the 107 control subjects reacted with pancreas, salivary gland, pituitary, stomach, kidney, liver, oesophagus or skin. 

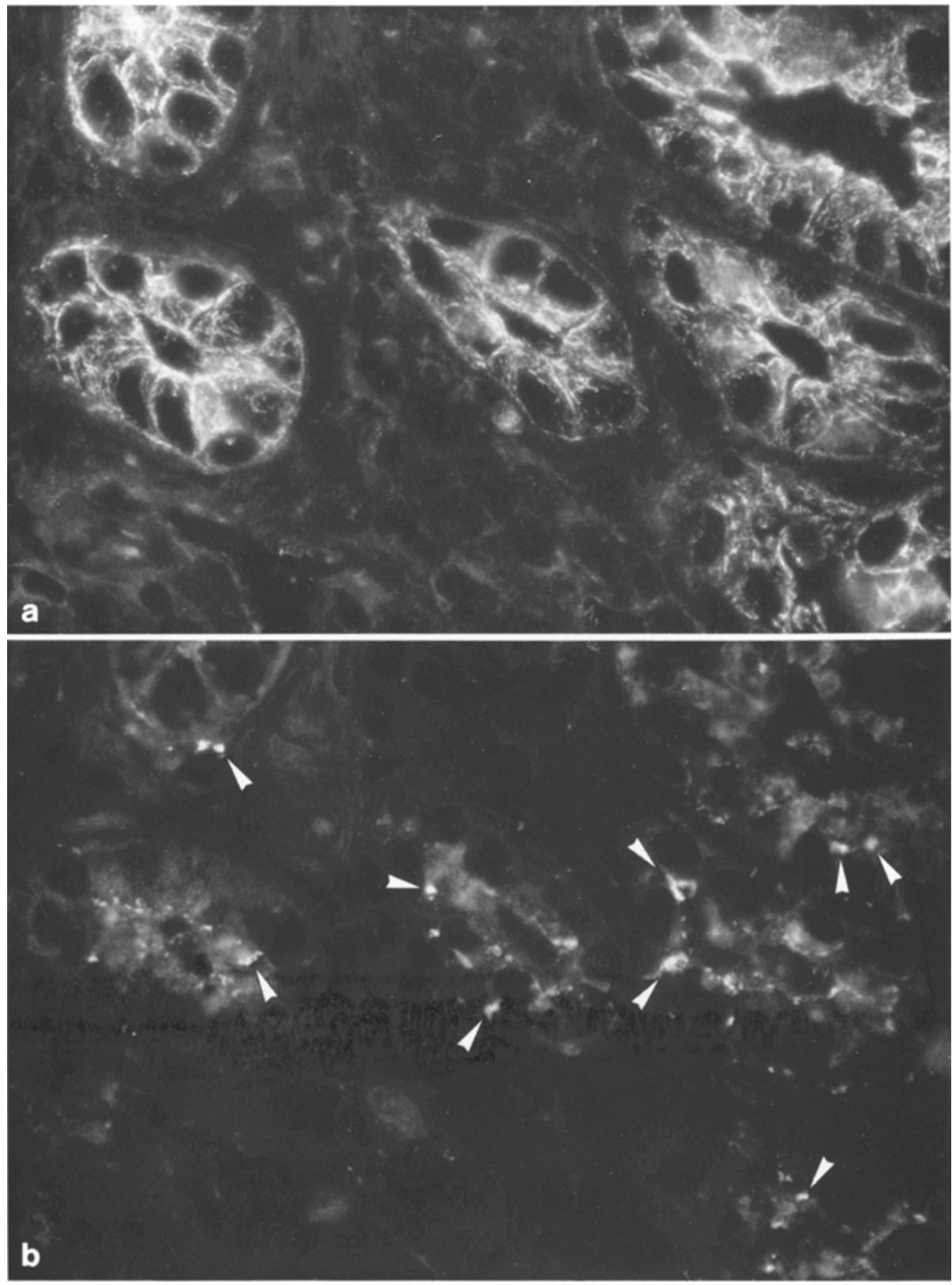

Fig. 4 a,b. Serial sections of human gastric mucosa stained by serum from a patient with Type 1 (insulin-dependent) diabetes mellitus (a) and by serum against pepsinogen (b). The positive cells for a "fine fibrillar" cytoplasmic cytokeratin stained by the patient's serum (a) were also positive for pepsinogen granules (arrowheads) (b), suggesting that the glandular cells reacting with the patient's serum were gastric chief cells. Original magnification: $\times 200$

\section{Clinical correlations of autoantibodies to pancreatic cytokeratin in Type 1 diabetes patients}

Pancreatic cytokeratin autoantibodies (PKA) were detected in $39 \%$ (15/38) of the patients with Type 1 diabetes whose duration of diabetes was less than 3 months, and the prevalence of PKA decreased as the duration of diabetes increased (Fig. 5). PKA were of the IgM class in $87 \%(13 / 15)$ of recent-onset ( $<3$ months) patients, and IgG-PKA became more prevalent in the subjects with a longer duration of diabetes (Fig. 5). The PKA titre expressed by dilution ratio of the sera ranged from 4 to 256 (Table 1). There was no difference between PKA-positive Type 1 diabetic patients and PKA-negative patients in terms of sex ratio $(\mathrm{M} / \mathrm{F})\left[11 / 12\left(\mathrm{PKA}^{+}\right)\right.$vs $\left.41 / 43\left(\mathrm{PKA}^{-}\right)\right]$ and age at onset $\left[21 \pm 3\right.$ years $\left(\mathrm{PKA}^{+}\right)$vs $28 \pm 2$ years $\left.\left(\mathrm{PKA}^{-}\right)\right]$. The titres of PKA in 3 Type 1 diabetic patients, who were followed up to 14 months after the clinical onset, decreased with the duration of diabetes (Fig. 6). The longitudinal changes in titres of PKA did not correlate well with those of ICA. Interestingly, the decrease in the titre of PKA was accompanied by the decline of abnormally elevated pancreatic-specific elastase-1 level in two cases (Fig. 6). The detailed clinical course in these two cases was described elsewhere [3]. Three (one father, one sibling, and one offspring) of four PKA-positive first-degree relatives of Type 1 diabetic patients also had ICA. One father and one offspring, who were positive for both PKA and ICA, showed mild glucose intolerance.

There was a positive association between PKA and ICA positivity in patients with Type 1 diabetes: PKA were positive in $28 \%(17 / 60)$ of the ICA-positive subjects, but in only $13 \%(6 / 47)$ of the ICA-negative subjects $(p=0.05)$. In addition, a significant correlation was demonstrated between the titres of PKA and those of ICA $\left(r_{\mathrm{s}}=0.63\right.$, $p<0.01, n=23$, Fig. 7). 


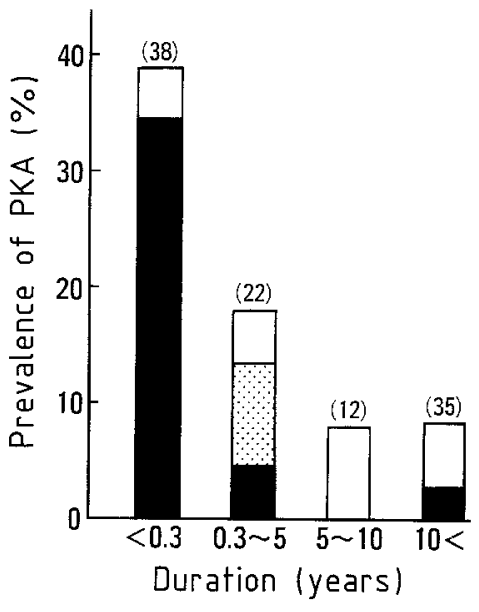

Fig.5. The prevalence of pancreatic cytokeratin autoantibodies (PKA) in Type 1 (insulin-dependent) diabetic patients. PKA became less prevalent with the duration of diabetes, and the Ig subclass of PKA switched from $\operatorname{IgM}$ to $\operatorname{IgG}$. The numbers in parentheses indicate the number of patients tested for PKA. PKA-IgM; PKA-IgM + IgG; $\square$ PKA-IgG
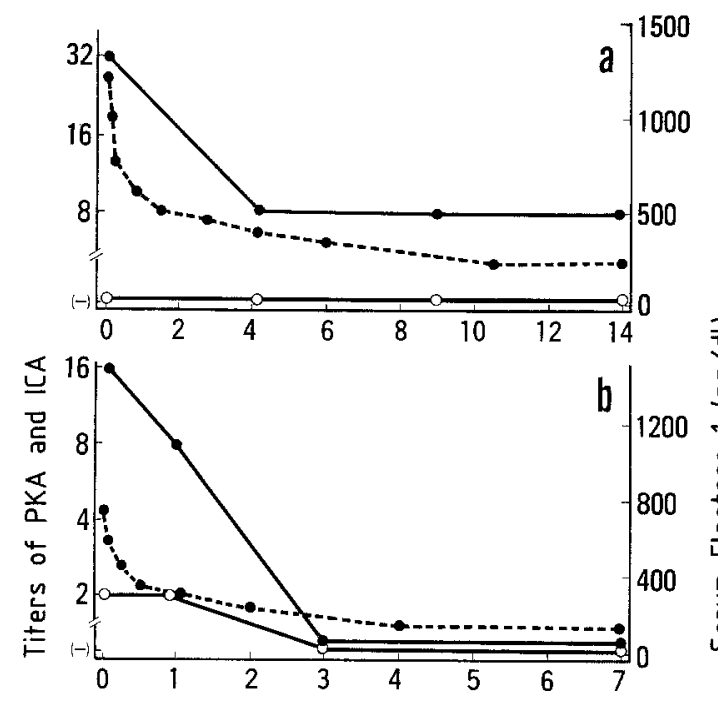

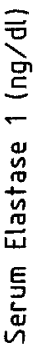

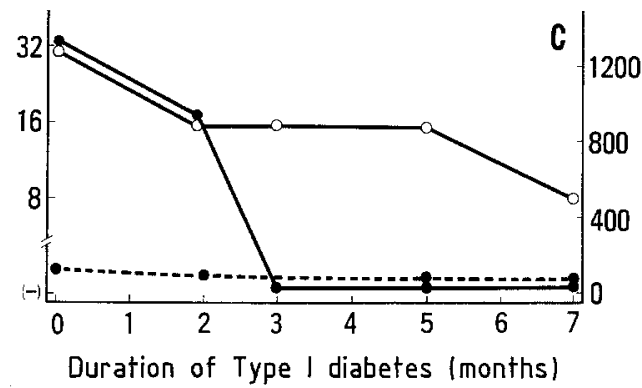

Fig. 6 a-c. Longitudinal changes in the titres of pancreatic cytokeratin autoantibodies (PKA), islet cell antibodies (ICA), and serum pancreatic specific elastase 1 levels in three patients with Type 1 diabetes [a: case 1 ( 45 year, M), b: case 2 ( 30 year, M), c: case 3 (23 year, F)]. In case 1 and 2 , elevated levels of elastase 1 ( well as PKA $(\bullet)$ decreased with the duration of disease. $0-0$ : ICA (For the conversion of the titre of ICA to JDF unit, multiply 5 to the titre presented in the figure.)

\section{Discussion}

We report here the presence of distinct autoantibodies to pancreatic exocrine cells in newly-diagnosed patients with Type 1 diabetes. Double-immunostaining indicated that the antibodies were directed against pancreatic cytokeratin, and immunoblotting analysis demonstrated that the antigen was a 40 kilodalton cytokeratin peptide.
Table 1. Frequency distribution on the titre of pancreatic cytokeratin autoantibodies in the subjects

\begin{tabular}{|c|c|c|c|c|}
\hline \multirow[t]{2}{*}{ Titre } & \multicolumn{2}{|c|}{ Type 1 diabetic patients } & \multirow{2}{*}{$\begin{array}{l}\text { First-degree } \\
\text { relatives of } \\
\text { Type } 1 \text { diabetic } \\
\text { patients } \\
n\end{array}$} & \multirow{2}{*}{$\begin{array}{l}\text { Type } 2 \\
\text { diabetic } \\
\text { patients } \\
n\end{array}$} \\
\hline & $\begin{array}{l}\text { Duration } \\
<3 \text { months } \\
n\end{array}$ & $\begin{array}{l}\text { Duration } \\
>3 \text { months } \\
n\end{array}$ & & \\
\hline Negative & 23 & 61 & 16 & 344 \\
\hline 1: 4 & & 1 & 1 & 1 \\
\hline 1: 8 & 1 & 2 & 2 & 1 \\
\hline 1: 16 & 3 & 2 & 1 & 1 \\
\hline 1: 32 & 4 & 2 & & \\
\hline 1: 64 & 4 & 1 & & \\
\hline $1: 128$ & 2 & & & \\
\hline \multirow[t]{2}{*}{$1: 256$} & 1 & & & \\
\hline & 38 & 69 & 20 & 347 \\
\hline
\end{tabular}

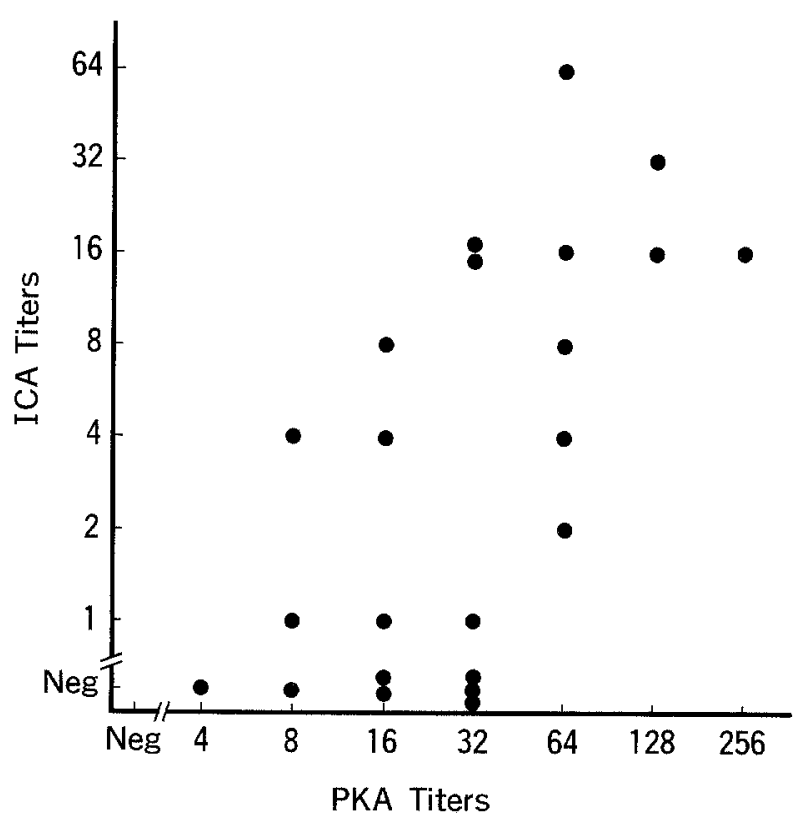

Fig. 7. Correlation between the titre of pancreatic cytokeratin autoantibodies (PKA) and that of islet cell antibodies (ICA) in PKApositive subjects with Type 1 diabetes. $r s=0.63, p<0.01$

Cytokeratin filaments are a family of intermediate filaments (IFs), which constitute a part of the cytoskeletal system [17-19]. They are present in the cells of epithelial origin, where they play a role in the cellular framework and also in the organization of relations between the plasma membrane, cytoplasm and nucleus [20]. The subunits of cytokeratin filaments are composed of at least 19 polypeptides, and the keratin filaments expressed are extremely variable, depending on the organ and the stage of cellular differentiation $[17,18]$. In pancreatic exocrine cell cytoplasm at least three types of cytokeratin polypeptides, including 40 kilodalton (cytokeratin number 19), 45 kilodalton (number 18) and 52.5 kilodalton (number 8 ) peptides, have been documented [17]. It cannot be ruled out that the patients' sera failed to react with other types of pancreatic cytokeratin during immunoblotting analysis because some of the human autoantibodies to cytoskeletal components were unable to react with SDS-denatured antigens on immunoblotting [21]. 
The mechanism of the occurrence of PKA remains speculative. Mild to moderate lymphocytic infiltration around pancreatic acinar cells as well as islet cells and elevation of the serum levels of pancreas-specific enzymes have been reported in Type 1 diabetes $[1-3,22]$. Furthermore, severe atrophy of the exocrine pancreatic tissues has been described in some ICA-positive patients with Type 1 diabetes [23]. These results suggest that both the exocrine and the endocrine pancreas are involved in the pathogenesis of Type 1 diabetes. It is noteworthy that in a few cases studied higher PKA titre at the clinical onset of Type 1 diabetes was accompanied by elevated serum level of pancreas specific elastase- 1 followed by subsequent decrease of this enyzme (Fig. 6). Therefore, it is possible that antibodies to pancreatic cytokeratin may be raised as a consequence of pancreatic exocrine cell damage. It may be related to viral insults [24]. IFs have been documented to play an important role in the replication and assembly of viruses [25-27]. Sharpe et al. [26] have reported that cytoplasmic IFs from cultured cells infected with reovirus types 1 and 3, which are associated with virus-induced diabetes in animals [28], were surrounded by viral inclusions and became markedly disrupted. Thus, it is conceivable that the release of antigenically altered IFs from virally infected cells may provide the stimulus for autoantibody production. Autoantibodies to IFs of neural cells (neurofilaments) are also reported in degenerative diseases such as kuru and Creutzfeldt-Jakob disease [29]. In addition, the presence of autoantibodies to microtubules has been reported in Type 1 diabetes [30], however organ-specificity was not examined. Another possibility for the occurrence of pancreatic cytokeratin autoantibodies may be the existence of molecular mimicry between viral proteins and human IFs proteins $[31,32]$. Sequence homologies have been reported between Epstein-Barr virus and cytokeratin peptides [31]. Viral infection may raise $\operatorname{IgM}$ antibodies, which then cross-react with cytokeratin peptides. Such antibodies would later switch to the IgG class. Some viral infections were associated with IgM autoantibodies to cytoplasmic IFs [33-35]. Recently, the presence of IgM surface autoantibodies, which were polyreactive with pituitary cells and lymphocytes, was reported in recent-onset Type 1 diabetic patients $[36,37]$. The possibility cannot be ruled out that pancreatic cytokeratin autoantibodies could be natural antibodies, which were produced by CD5-positive B cells [38]. Such natural antibodies are quickly enhanced in response to exogenous antigens in the course of viral, bacterial or parasitic infections, and almost all of the antibodies are $\operatorname{IgM}$ with capacity to bind with multiple antigens [39]. Further study on the polyreactivity of cytokeratin autoantibodies to a variety of antigens may contribute to characterize the nature of the autoantibodies. Autoantibodies to the keratinized layers of the skin or oesophagus have also been reported in rheumatic diseases including RA, systemic lupus erythematosus, and Sjögren's syndrome $[21,40,41]$. In the present study, none of the Type 1 diabetic sera positive for pancreatic cytokeratin were positive for the keratinized zone of human skin.

The cross-reactivity of pancreatic exocrine cell cytokeratin autoantibodies with cytokeratin filaments of the pancreatic islet and gastric chief cells is of great interest, because this suggests a common endodermal origin for pancreatic acinar cells, islet cells, and gastric chief cells. The possibility cannot be ruled out that the primary antigen of cytokeratin autoantibodies belongs to cytokeratin of the islet cell or gastric chief cell. Recently, the presence of a 40 kilodalton cytokeratin peptide was reported in the normal pancreatic islets [42].

PKA could be a pathogenetic factor responsible for pancreatic exocrine or endocrine cell damage in Type 1 diabetes, since the cytoskeletal system anchors the terminal to the plasma membrane [20], and shares antigenic determinants with some membrane proteins [43,44]. Diaz et al. [45] suggested that cytokeratin autoantibody from the patients with pemphigus was able to recognize an extracellular domain to a specific cytokeratin.

Different "fine fibrillar" pattern of cytokeratin in our study (Figs. $1 \mathrm{a}$ and $\mathrm{b}$ ) from previous studies $[18,43,44]$ may be explained by the different substrate and treatment used. We used unfixed and acetone-fixed cryostat human tissue sections for detecting cytokeratin autoantibodies to examine an organ-specificity, while other studies $[18,43$, 44] dealing with cytoplasmic structure used fixed cultured cells.

In conclusion, autoantibodies against the cytokeratin of pancreatic acinar cell were detected in some newly-diagnosed patients with Type 1 diabetes, suggesting that the exocrine pancreas as well as the pancreatic islet is involved in the pathogenetic process of Type 1 diabetes.

Acknowledgments. We wish to thank Dr. M.Hara (Department of Pathology, Toranomon Hospital) for his helpful comments, Mr. H. Tsukahara and Mr. S. Uchibori for their generous assistance, and Ms. M. Amatatsu and Ms. F. Takano for excellent secretarial work. This work was supported in part by the Japanese Ministry of Education, Science, and Culture Research Grants no.63570556, no. 01570662 and by a grant from the Ministry of Health and Welfare of Japan.

\section{References}

1. Kobayashi T, Nakanishi K, Sugimoto T, Murase T, Kosaka K (1988) Histopathological changes of the pancreas in islet cell antibodies (ICA)-positive subjects before and after the clinical onset of insulin-dependent diabetes mellitus (IDDM). Diabetes 37: 24 (Abstract)

2. Kobayashi T, Nakanishi K (1987) Natural history of type I diabetes and slowly progressive IDDM: a histopathological study. J Jpn Diab Soc 30: 1152-1154

3. Nakanishi K, Kobayashi T, Sugimoto T, Murase T, Itoh T, Kosaka K (1988) Does pan-pancreatic involvement occur in IDDM? Diabetes Care 11: 100-101

4. Frier BM, Saunders JHB, Wormsley KG, Bouchier IAD (1976) Exocrine pancreatic function in juvenile-onset diabetes mellitus. Gut 17: 685-691

5. Lankisch PG, Manthey G, Otto J, Koop H, Talaulicar M, Willms B (1982) Exocrine pancreatic function in insulin-dependent diabetes mellitus. Digestion 25: 211-216

6. Thal AP, Murray MJ, Egner W (1959) Isoantibody formation in chronic pancreatic disease. Lancet I: $1128-1129$

7. Lankisch PG, Koop H, Seelig R, Seelig HP (1981) Antinuclear and pancreatic acinar cell antibodies in pancreatic diseases. Digestion 21: 65-68

8. Lendrum R, Walker G (1975) Serum antibodies in human pancreatic disease. Gut 16: 365-371 
9. Villavicencio E, Thurnau G, Goetz FC (1965) Isoantibodies to human pancreas: a preliminary report. Diabetes 14: 226-228

10. Ivarsson SA, Marner B, Lernmark $\AA$, Nilsson KO (1988) Nonislet pancreatic autoantibodies in sibship with permanent neonatal insulin-dependent diabetes mellitus. Diabetes 37:347-350

11. National Diabetes Data Group (1979) Classification and diagnosis of diabetes mellitus and other categories of glucose intolerance. Diabetes 28: 1039-1057

12. Steinert PM, Aynardi-Whitman M, Zackroff RV, Goldman RD (1982) Isolation and characterization of intermediate filaments. In: Wilson LA (ed) Methods and perspectives in cell biology, Part A. Academic Press, New York, pp 399-408

13. Laemmli UK (1970) Cleavage of structural proteins during the assembly of the head of bacteriophage T4. Nature 227: 680-685

14. Kobayashi T, Sugimoto S, Itoh T, Kosaka K, Tanaka T, Suwa S, Sato K, Tsuji K (1986) The prevalence of islet cell antibodies in Japanese insulin-dependent and non-insulin-dependent diabetic patients studied by indirect immunofluorescence and by a new method. Diabetes 35: 335-340

15. Kobayashi T, Itoh T, Kosaka K, Sato K, Tsuji K (1987) Time course of islet cell antibodies and B-cell function in non-insulindependent stage of type 1 diabetes. Diabetes 36: 510-517

16. Ohyama T, Kawamura K, Orimo H, Murakami M (1978) Radioimmunoassay method for measurement of quantity of pancreatic elastase-1 in human serum. J Clin Exp Med (Japan) 105: 91-97

17. Moll R, Franke WW, Schiller DL, Geiger B, Krepler R (1982) The catalog of human cytokeratins: patterns of expression in normal epithelia, tumors and cultured cells. Cell 31: 11-24

18. Tseng SCG, Jarvinen MJ, Nelson WG, Huang JW, WoodcockMitchell J, Sun TT (1982) Correlation of specific keratins with different types of epithelial differentiation: monoclonal antibody studies. Cell 30:361-372

19. Lazarides $E$ (1980) Intermediate filaments as mechanical integrators of cellular space. Nature 283:249-256

20. Geiger B (1987) Intermediate filaments: looking for a function. Nature 329: 392-393

21. Kurki P, Virtanen I (1984) The detection of human antibodies against cytoskeletal components. J Immunol Methods 67: 209-223

22. Yoon JW, Austin M, Onodera T, Notkins AL (1979) Virus-induced diabetes mellitus: isolation of a virus from the pancreas of a child with diabetic ketoacidosis. N Engl J Med 300: 1173-1179

23. Nakanishi K, Kobayashi T, Sugimoto T, Murase T, Itoh T, Kosaka K, Hara M (1988) Inverse relationship between residual betacells and exocrine pancreas in insulin-dependent diabetics. Diab Res Clin Prac [Suppl. 1]: S53 (Abstract)

24. Rayfield EJ, Seto $Y$ (1978) Viruses and the pathogenesis of diabetes mellitus. Diabetes 27: 1126-1139

25. Lenk R, Penman S (1979) The cytoskeletal framework and poliovirus metabolism. Cell 16: 289-301

26. Sharpe AH, Chen LB, Fields BN (1982) The interaction of mammalian reoviruses with the cytoskeleton of monkey kidney CV-1 cells. Virology 120: 399-411

27. Murti KG, Goorha R (1983) Interaction of frog virus-3 with the cytoskeleton: altered organization of microtubules, intermediate filaments, and microfilaments. J Cell Biol 96: 1248-1257

28. Onodera T, Toniolo A, Ray UR, Jenson B, Knazek RA, Notkins AL (1981) Virus-induced diabetes mellitus: XX. Polyendocrinopathy and autoimmunity. J Exp Med 153: 1457-1473

29. Sotelo J, Gibbs CJ, Gajdusek DC (1980) Autoantibodies against axonal neurofilaments in patients with kuru and CreutzfeldtJakob disease. Science 210: 190-193

30. Rousset B, Vialettes B, Bernier-Valentin F, Vague P, Beylot M, Mornex R (1984) Anti-tubulin antibodies in recent onset Type 1 (insulin-dependent) diabetes mellitus: comparison with islet cell antibodies. Diabetologia 27: 427-432
31. Walker EJ, Jeffrey PD (1986) Polymyositis and molecular mimicry, a mechanism of autoimmunity. Lancet II: $605-607$

32. Fujunami RS, Oldstone MBA, Wroblewska Z, Frankel ME, Koprowski H (1983) Molecular mimicry in virus infection: crossreaction of measles virus phosphoprotein or of herpes simplex virus protein with human intermediate filaments. Proc Natl Acad Sci USA 80: 2346-2350

33. Toh BH, Yildiz A, Sotelo J, Osung O, Holborow EJ, Kanakoudi F, Small JV (1979) Viral infections and IgM autoantibodies to cytoplasmic intermediate filaments. Clin Exp Immunol 37: 76-82

34. Bretherton L, Toh BH (1981) IgM autoantibody to intermediate filaments in infectious mononucleosis. J Clin Lab Immunol 5: $7-10$

35. Pedersen JS, Toh BH, Locarnini SA, Gust ID, Shyamala GNS (1981) Autoantibody to intermediate filaments in viral hepatitis. Clin Immunol Immunopathol 21: 154-161

35. Vercammen M, Gorus F, Foriers A, Segers O, Somers G, Van de Winkel M, Pipeleers D (1989) Cell surface antibodies in Type 1 (insulin-dependent) diabetic patients. I. Presence of immunoglobulins $\mathrm{M}$ which bind to rat pituitary cells. II. Presence of immunoglobulins $M$ which bind to lymphocytes. Diabetologia 32: 611-617

37. Segers O, Gorus F, Somers G, Van de Winkel M, Vercammen M, Pipeleers D (1989) Cell surface antibodies in Type 1 (insulin-dependent) diabetic patients. II. Presence of immunoglobulins $\mathrm{M}$ which bind to lymphocytes. Diabetologia 32: 618-623

38. Nakamura M, Burastero SE, Notkins AL, Casali P (1988) Human monoclonal rheumatoid factor-like antibodies from CD5 (Leu-1) ${ }^{+}$B cells are polyreactive. J Immunol 140: $4180-4186$

39. Casali P, Notkins AL (1989) $\mathrm{CD}^{+}$B lymphocytes, polyreactive antibodies and the human B-cell repertoire. Immunolo Today 10: 364-368

40. Young BJJ, Mallya RK, Leslie RDG, Clark CJM, Hamblin TJ (1979) Anti-keratin antibodies in rheumatoid arthritis. Br Med J 2:97-99

41. Kataaha PK, Mortazavi-Milani SM, Russell G, Holborow EJ (1985) Anti-intermediate filament antibodies, antikeratin antibody, and antiperinuclear factor in rheumatoid arthritis and infectious mononucleosis. Ann Rheum Dis 44: 446-449

42. Ulrich K, Schubart K, Fields KL (1984) Identification of a calcium-regulated insulinoma cell phosphoprotein as an islet cell keratin. J Cell Biol 98: 1001-1009

43. Dulbecco R, Unger $M$, Bologna $M$, Battifora $H$, Syka $P$, Okada S (1981) Cross-reactivity between Thy-1 and a component of intermediate filaments demonstrated using a monoclonal antibody. Nature 292: 772-774

44. Dales S, Fujinami RS, Oldstone MBA (1983) Serologic relatedness between Thy-1.2 and actin revealed by monoclonal antibody. J Immunol 131: 1332-1338

45. Diaz LA, Sampaio SAP, Martins CR, Rivitti EA, Macca ML, Roscoe JT, Takahashi Y, Labib RS, Patel HP, Mutasim DF, Dugan EM, Anhalt GJ (1987) An autoantibody in pemphigus serum, specific for the $59 \mathrm{kD}$ keratin, selectively binds the surface of keratinocytes: evidence for an extracellular keratin domain. J Invest Dermatol 89: 287-295

Received: 28 September 1989

and in revised form: 2 January 1990

Dr. T. Kobayashi

Department of Endocrinology and Metabolism

Toranomon Hospital, 2-2-2 Toranomon

Minato-ku

Tokyo 105, Japan 